\title{
A Study on Hydraulic Modifications of Low-Pressure Membrane Inlet Structure with CFD and PIV Techniques
}

\author{
오정익 · 최종웅* · 임재림* · 김동길** - 박노석**, ${ }^{\dagger}$ \\ Jeong Ik Oh · Jong-Woong Choi* · Jae-Lim Lim* • Donggil Kim** ${ }^{*}$ No-Suk Park**, ${ }^{\dagger}$ \\ $\mathrm{LH}$ 연구원 · *K-water 연구원 · **경상대학교 토목공학과 및 공학연구원 \\ LH Institute * *K-water Institute \\ **Department of Civil Engineering and Engineering Research Institute, Gyeongsang National University
}

(Received November 4, 2015; Revised November 12, 2015; Accepted November 16, 2015)

\begin{abstract}
This study was conducted to suggest hydraulic modification for improving evenness of inlet flow distribution into side stream type low-pressure MF (microfiltration) module using CFD (computational fluid dynamics) simulation and PIV (particle image velocimetry) techniques. From the results of CFD simulation for various typed inlet structure, it was investigated that installing internal orifice baffle in inlet the distribution channel could improve the evenness of inlet flow distribution over about $40 \%$. Also, from the results of PIV measurements which were carried out for verifying the CFD simulation, it was observed that the momentum of the water body coming from the opposite side of the inlet was relatively larger. This momentum would generate strong shear force in the near of inlet side wall. On the other hands, occurrence of dead zone and eddy flow was confirmed in the opposite side. Key Words : Evenness of Flow Distribution, Side Stream Type MF Module, Hydraulic Modification, Computational Fluid Dynamics (CFD), Particle Image Velocimetry (PIV)
\end{abstract}

요약 : 본 연구에서는 CFD 모사와 PIV 기법을 이용하여 실규모의 사이드 스트림 방식의 막 모듈을 대상으로 유입부의 수리 구조를 개선하여 모듈로 유입되는 유입 유량을 수직으로 균등하게 분포시킬 수 있는 방안을 제시하고 이를 실험적으로 검증 하고자 하였다. 사이드 스트림 방식의 막 모듈을 대상으로 유입 유량을 수직으로 균등하게 분포시킬 수 있는 방안을 CFD로 설계한 결과, 내부 유입 수리구조에 유공 격벽을 설치함으로써 모듈내로의 유입유량은 표준편차 기준으로 약 $40 \%$ 정도 감소 됨을 확인하였다. 또한 $\mathrm{CFD}$ 결과를 검증하고 사이드 스트림 막 모듈의 편중된 오염의 원인을 조사하기 위해 수행된 입자영 상유속 측정 결과로부터 유입구 반대편 유공에서 막 모듈 내부로 들어오는 수체의 유속이 상대적으로 커 수체의 모멘텀이 유입구 측벽에 강한 전단력을 발생하지만 유입구 반대 측벽에서는 사류가 형성됨을 확인하였다.

주제어 : 유량 분배 균등성, 사이드 스트림 방식 정밀여과 막 모듈, 수리구조 개선, 전산유체역학, 입자영상유속계

\section{1. 서 론}

수처리 공정에서 정밀여과(microfiltration) 및 한외여과(ultrafiltration) 등의 저압막 여과공정은 막 세공(pore) 전 · 후 단에 압력차를 가하여 세공보다 큰 오염물질을 체거름 현상 에 의해 선택적으로 입자를 제거하는 기작을 이용하는 것 이다. ${ }^{1)}$ 일반적인 정수처리에 있어서 고액 분리의 마지막 공 정인 모래여과에 비해 처리의 안정성, 운영의 자동화 및 용 이성, 소요 부지의 저감 등에서 많은 장점이 있으나, 상대 적으로 높은 운영 및 유지관리 비용으로 아직까지 도입 속 도가 제한적이었다. ${ }^{2)}$ 그러나 최근 운영기술의 발달 및 막 모듈 생산 단가의 감소 등 경제성이 향상되면서 점차 대규 모 정수장의 수처리 공정에 적용을 확대하고자 하는 움직 임이 활발하게 일어나고 있다. 바이러스, 박테리아 및 원생 동물(예: Giardia 또는 Cryptosporidium 등)과 원인 불명의 입자성 오염물질 등의 출현은 수돗물의 생산 및 공급에 있 어서 경제성 보다 안전성을 중요시하는 인식을 제고하였고 이에 따라 2000년대 초반부터 막 공정의 적용 속도는 과거
10 년에 비해 $60 \%$ 이상 상승하였다. ${ }^{3,4)}$

막 여과공정은 주기적인 물리적 역세척을 수반하지만 장 기간 입자를 제거함에 따라 물리적 역세척으로 회복시킬 수 없는 세공 막힘 현상이 발생하며(비가역 오염), 이러한 경 우 화학 세정을 수행하여 세공을 오염시킨 물질을 제거시 켜 주거나, 막 모듈을 교체하여야 한다. ${ }^{5)}$ 따라서 이제까지 는 이러한 막 모듈의 오염을 줄여 화학세정 주기 및 사용 연한을 연장하기 위한 -궁극적으로 운영 및 유지관리비 저 감을 목적으로 하는-연구에 많은 노력들이 집중되어왔다. ${ }^{\circ}$ 어떤 연구자들은 응집 전처리를 통해서 원수의 유기물을 응결시켜 막 공정의 제거효율을 높이고 오염 가능성을 감 소시킨 연구를 수행하였으며, ${ }^{7,8)}$ 또한 어떤 연구자들은 전처 리 공정으로 활성탄 및 막 오염 저감을 위한 특정 흡착물 질을 이용한 흡착(adsorption) 공정을 두어 고분자 유기물을 막 공정 전단에서 제거하는 방안을 제시하기도 하였다. ${ }^{9,10)}$ 전처리 공정으로 산화 공정을 두어 NOM (Natural Organic Matters)을 막 공정 전단에서 제거하여 막오염을 저감하는 방안을 연구하기도 하였으며, ${ }^{11,12)}$ 또한 다른 연구자들은 세 
공의 크기가 조금 더 큰 막이나 스트레이너, 입상 여재를 이 용하여 전처리로써 또 다른 여과공정 도입의 효율성을 입증 하기도 하였다. ${ }^{12,13)}$

그런데 저자가 비가역적 오염을 감소시킬 수 있는 방안의 문헌 연구를 수행한 결과 대부분의 연구가 막 공정 전단의 전처리 방법 및 소재의 친수성 여부를 조정하는 분야에 집 약되어 있었다. 기존 정수처리 공정 중 침전공정이나 모래 여과공정의 효율을 결정하는 중요한 요소 중에 하나는 공 정 내부의 수리흐름을 들 수 있다. ${ }^{15,16)}$ 막 공정 또한 공극 저항체(porous media)를 포함하는 관수로와 유사한 유체 흐 름으로 간결화할 수 있으며, 유체 내 물질전달 및 Darcy 법 칙에 근간하여 고액 분리를 도모하는 공정임에도 불구하고 막 모듈 내부 수리 조건의 최적화를 목적으로 하는 연구는 거의 없다.

다음 Fig. 1은 실제 막 공정 정수처리 플랜트에서 약 4년 간 운전된 사이드 스트림(side stream) 막 모듈의 절단면을 보여주고 있다. 막 모듈은 역세척이 수행된 직후의 상태이 며, 그림에 도시한 바(Fig. 1(a))와 같이 사이드 스트림 막 모 듈 유입구 반대편에 오염이 편중되어 있는 현상이 나타났다. 이와 같은 현상은 막 모듈의 길이 방향으로도 편중된 오염 현상이 나타나고 있는데(Fig. 1(b)) 이는 막 모듈로 유입된 유입수가 축 방향으로 편향된 흐름이 나타나기 때문이다. 또한 오염이 Fig. 1과 같이 막 모듈내에서 편중되게 나타나 는 현상은 역세척 시 공기 및 물이 균등하게 막 모듈 내에 전반적으로 골고루 전달되지 못하는 것에도 기인한 현상이 다. 아직까지 편중된 막 모듈 내 오염 현상을 과학적으로 규 명한 사례는 없지만 막 공정을 설계한 전문가들의 의견을 참조하면 이러한 편중된 막 오염 현상이 발생하는 지역에 지속적으로 가압을 하여 물을 생산하는 경우 물리적으로 회복이 가능한 가역 오염(reversible fouling)이 비가역 오염 (irreversible fouling)으로 변화될 가능성이 있다고 한다. 그 러한 경우 화학 세정의 주기와 막 사용 연한이 감소할 것으 로 예측하고 있다.

케이싱 저압막 모듈은 크게 하부에서 유입수가 막 모듈로 유입되는 방식과 측면에서 유입수가 유입되는 사이드 스트 림 방식으로 구분되는데, 하부에서 유입수가 유입되는 방 식의 경우 하부 배관 구조 설치를 위해 막 공정을 설치하 는 구조물의 층고가 상대적으로 더 소요되는 단점을 가지고 있다. 이에 반해 사이드 스트림 방식의 막 모듈을 운전하는
경우는 상기 Fig. 1과 같이 막 모듈내로 유입되는 유입수의 불균등 분포가 편중된 오염을 발생하는 단점이 나타났다. 본 연구의 대상이 되는 사이드 스트림 방식의 막 모듈 유입 유량의 불균등이 발생하면 막 모듈을 구성하는 할로우 파 이버(hollow fiber) 막의 사용이 편중되어 비가역 오염의 발 생이 가중될 가능성이 커지며 이에 화학 세정 주기가 예상 보다 감소하여 궁극적으로 사용연한이 줄어들 수 있는 가 능성이 매우 크다.

이에 본 연구에서는 실규모의 사이드 스트림 방식의 막 모듈을 대상으로 하단에 위치한 유입부의 수리구조를 개선 하여 모듈로 유입되는 유입 유량을 수직으로 균등하게 분 포시킬 수 있는 방안을 제시하고 이를 실험적으로 검증하 고자 하였다. 이를 위해서 수리구조 개선안을 전산유체역학 (computational fluid dynamics, CFD)기법으로 사이드 스트 림 방식의 막 모듈 유입 수리구조를 여러 가지 형태로 모 사하였고, 모사 결과를 해석하여 최적 설계안을 선정, 이를 데모 버전으로 제작하여 입자영상유속(particle image velocimetry, PIV)장치를 이용하여 기존 대비 막 모듈내 유입 유 량의 균등성을 실측하였다.

\section{2. 이론적 배경}

본 연구의 대상인 사이드 스트림 방식의 막 모듈은 Fig. 2 사진에 나타낸 것과 같다. 측면 유입구(직경 $\mathrm{D}=52 \mathrm{~mm}$ )를

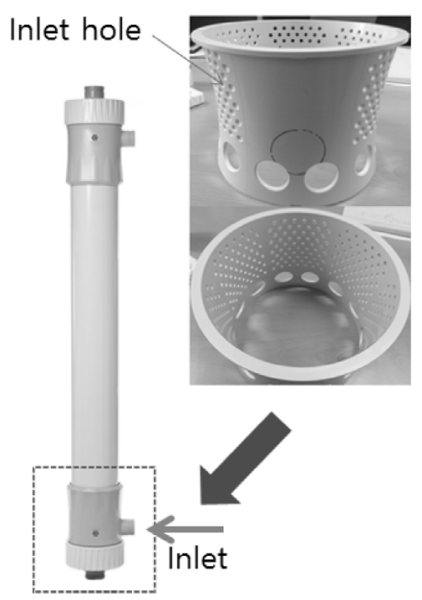

Fig. 2. Side stream type membrane module for this study.

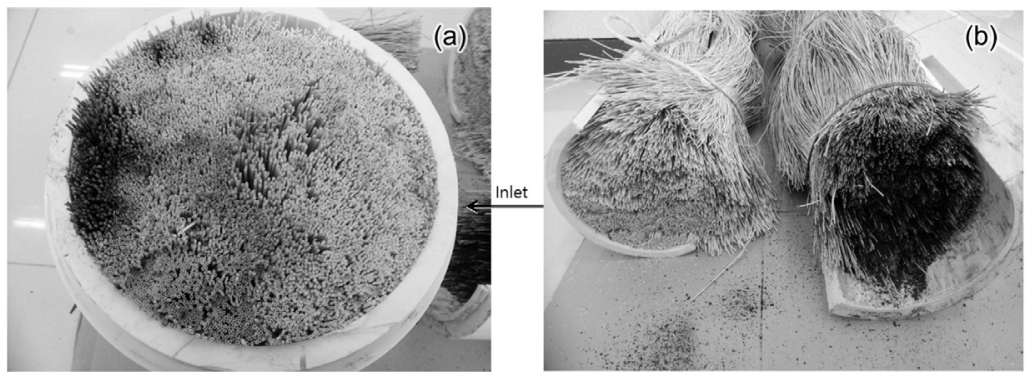

Fig. 1. Fouling Phenomena in side stream typed MF (microfiltration) membrane. 

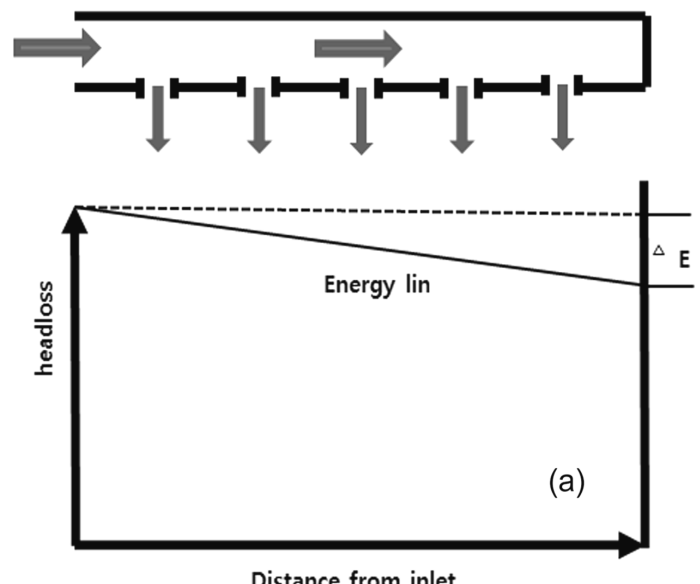

Fig. 3. Multi-outlet pipe and energy line.

들어간 물은 내부에 설치된 원형 유공(직경 $\mathrm{d}=5.2 \mathrm{~mm}$, 개 수 $\mathrm{n}=306)$ 격벽(baffle)을 통해 모듈 내부로 유입된다. 세 공 아래 부분의 큰 구멍(hole)은 물이 유입되는 부분이 아 니고 격벽 및 할로우 파이버 막을 고정시키기 위한 역할을 한다. 원형 유공 격벽 구조를 직선화시킨 것으로 가정하면 다음 Fig. 3(a)와 같이 다중 유출구가 있는 관수로로 생각할 수 있다. 간략화된 다중 유출 수로의 경우(Fig. 3(a)) 수로내 평균 유속이 작으면 벽면 마찰 손실로 하류로 갈수록 유출 구로부터 나가는 유출 유량이 작아지고, 반대로 평균 유속 이 상대적으로 크면 하류 끝단에서 에너지가 축적되어 수로 내 수두가 높아져 유출 유량이 증가하는 양상을 보인다. ${ }^{17)}$

이러한 문제를 해결하기 위한 방편으로 Fig. 3(b)는 일정 한 통수 단면적을 가진 수로에서 발생하는 각 유출 유량의 편차를 저감하기 위한 방안으로 수로 내에 유공 격벽을 하 나 더 설치하는 수리구조 개선의 개념도이다. ${ }^{17)}$ 자세히 설 명하면, 기존 수로의 중간에 유공 격벽을 설치함으로써 물 을 선회시키는 것인데, Fig. 3(b)에서 보는 바와 같이 유공 격벽 전단에는 (유입부에서 오른쪽으로 말단으로 가는 흐 름) 왼쪽이 오른쪽 보다 수두가 높고 후단에서는 (선회 후 왼쪽에서 오른쪽으로 가는 흐름)에서는 오른쪽이 왼쪽보다 수두가 높으므로 전단과 후단 사이에 유공을 통해 물이 통 과하면서 일정한 수두가 유지되는 것이다.

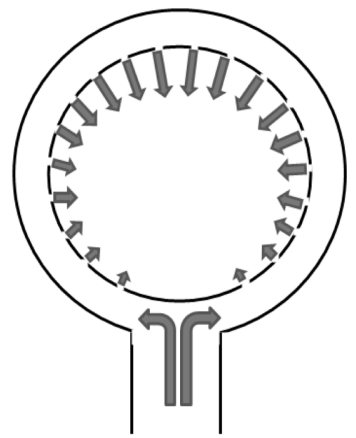

(a)

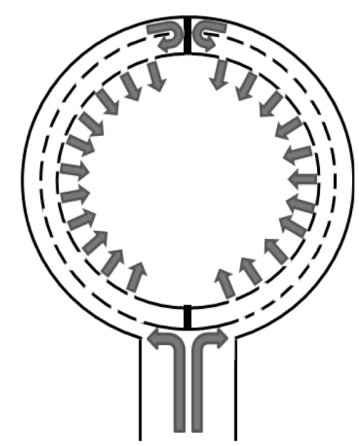

(b)
Fig. 4. Low pressure membrane inlet structure.

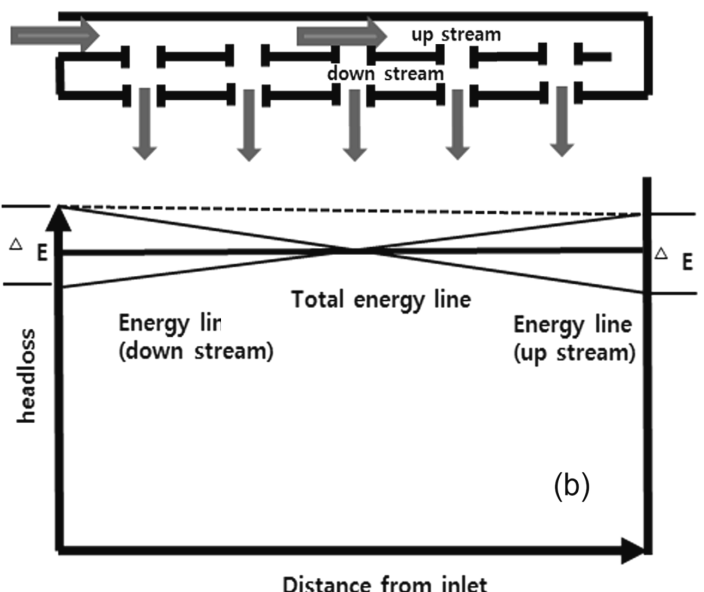

Fig. 4는 상기 Fig. 3의 유공 격벽이 있는 경우와 없는 경우 를 각각 원형화하였을 때 각 유공을 통해서 유출되는 유량 의 개념을 정리한 것이다. Fig. 4(a)는 중간 유공 격벽이 없는 경우를 나타내 유입되는 유량이 불균등하게 분포되는 경우 이고, (b)는 중간 유공 격벽을 설치하여 유입되는 유량이 균 등하게 내부로 유입되는 개념을 설명하고 있다.

\section{3. 연구 방법}

\section{1. 막 모듈 및 유공 격벽 형상}

본 연구의 대상이 된 저압 막 모듈의 유입부에는 Fig. 2와 같은 유공 격벽이 설치되어 있으며, 격벽의 유공을 통하여 주 흐름이 발생하여 막 모듈내로 유입된다. 다음 Table 1은 국내 K_사의 저압 Microfiltration (MF) 막 모듈의 제원을 정 리한 것이다. Fig. 5는 유공격벽의 제원을 도시한 것으로써 모듈 측벽 유입구의 직경은 $51.6682 \mathrm{~mm}$ 이며, 유입구를 통 해 유입된 물이 환형으로 분배되어 격벽의 유공 $\left(\mathrm{d}_{1}=5.1686\right.$ $\mathrm{mm})$ 을 통해 모듈 내로 유입된다. 물이 유입되는 내부 수로 의 높이 $\left(\mathrm{H}_{1}\right)$ 는 $94.7964 \mathrm{~mm}$ 이며, 수로 폭 $\left(\mathrm{B}_{1}\right)$ 은 약 $7.0 \mathrm{~mm}$ 정도인데 높이 방향으로 움푹 들어간 형상을 나타낸다.

Table 1. The membrane module specifications

\begin{tabular}{c|c|c|}
\hline $\begin{array}{c}\text { Membrane } \\
\text { type }\end{array}$ & $\begin{array}{c}\text { Microfiltration } \\
\text { (MF) }\end{array}$ \\
\hline \hline $\begin{array}{c}\text { Module mem- } \\
\text { brane area } \\
\text { Material }\end{array}$ & $70 \mathrm{~m}^{2}$ \\
Pore size & PVDF \\
Flux (LMH) & $0.1 \mu \mathrm{m}$ \\
Operation pH & $20-80$ & \\
Operation temp. & $1-40{ }^{\circ} \mathrm{C}$ \\
Case meterial & $\mathrm{PVC}$ & \\
Size & $\mathrm{D} 216 \mathrm{~mm} \times$ & \\
\hline $\mathrm{H} 2,230 \mathrm{~mm}$ & & $\begin{array}{l}\text { Module, inlet } \\
\text { structure and } \\
\text { baffle shape }\end{array}$ \\
\hline
\end{tabular}



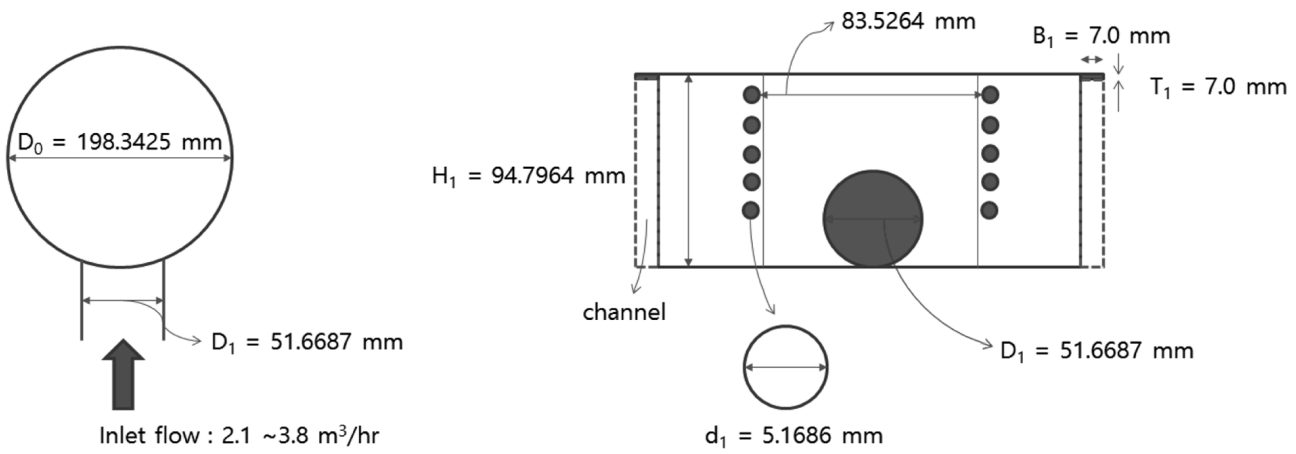

Fig. 5. Specifications of the baffle in the membrane module.

\subsection{CFD 해석 방법론}

\subsection{1. 형상 작업 및 경계 조건}

본 연구에서는 막 모듈 내부 유체 거동을 전산유체역학 기법으로 모사하기 위해서 상용 코드인 ANSYS CFX 15.0 을 사용하였다. ${ }^{18)}$ Fig. 6(a)는 막 모듈 입구부에 설치되어 있는 유공 격벽의 유로 향상이며, 점선으로 표시된 영역을 대상으로 유동해석을 수행하였다. Fig. 6(b)는 본 해석을 수 행하기 위한 대상 영역을 유동 영역과 porous 영역으로 구
성하였으며, 유입구에서 유입된 물은 격벽 유공을 통하여 porous 영역을 통하여 유출(outlet)되는 것으로 가정하였다. 정상 상태를 가정하였으며, 흐르는 유체의 특성은 $20^{\circ} \mathrm{C}$ 의 물이 유입되는 것으로 해를 구하였다.

다음 Fig. 7은 본 연구에서 수행한 총 4 case의 유입구 구 조를 도시한 것이다. Case 1은 대상 막 모듈 기존 형상(단일 유공 격벽)을 나타내었으며, case2, 3과 4는 막 모듈 유입수 로 중간에 또 다른 유공 격벽을 설치한 이중 격벽 유입구조 (a)

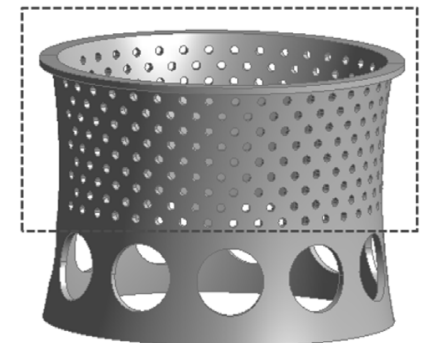

(b)

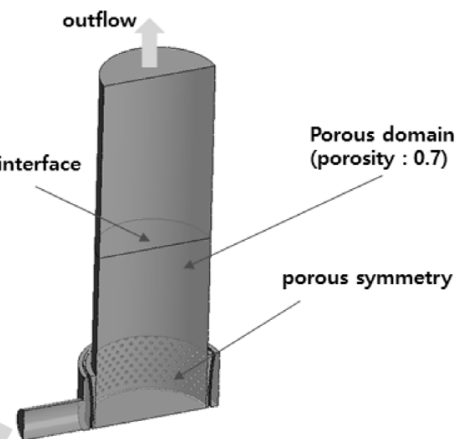

Fig. 6. Internal baffle geometry and Boundary conditions for CFD simulation.

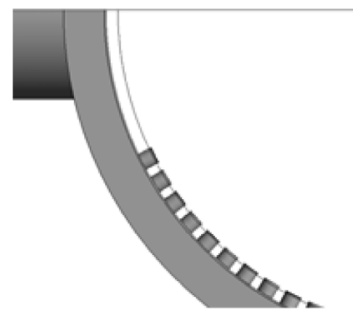

(a) Case 1 - without internal baffle (existing)

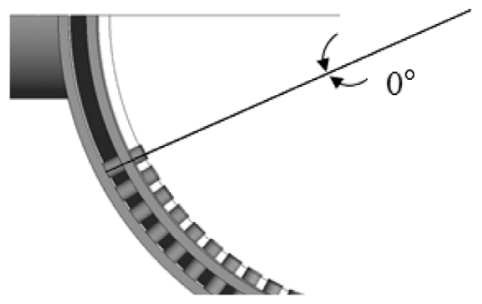

(c) Case 3 - with internal orifice baffle(angle between hole1and hole2: $0^{\circ}$ )

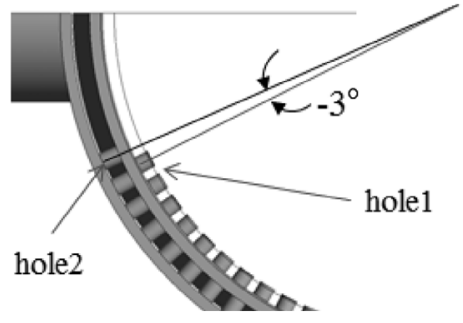

(b) Case 2 - with internal orifice baffle (angle between hole1 and hole2:-3)

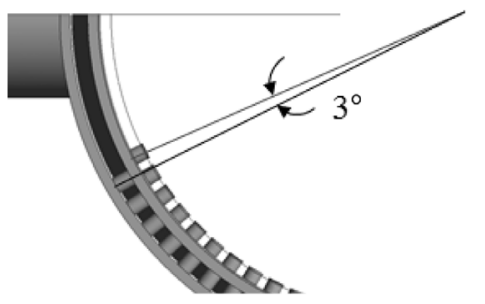

(d) Case 4 - with internal orifice baffle (angle between hole1and hole2: $3^{\circ}$ )

Fig. 7. Internal baffle and hole location (CFD simulation cases). 
를 적용한 것으로써 기존 격벽(외부) 유공과 내부 격벽 유공 의 중심을 기준으로 $-3^{\circ}, 0^{\circ}, 3^{\circ}$ 의 값을 갖는 형상을 나타내 었다. 이러한 조건을 선정한 것은 이론적으로 이중 격벽구 조가 유량의 균등 분배에 이상적이지만, 외부 기존 격벽의 반지름(R) 축소하여 내부에 설치하는 경우 기존 외부 격벽 과 신설하는 내부 간의 거리 및 유공의 직경이 $-3^{\circ}$ 에서 $3^{\circ}$ 까 지 유공의 중심이 이격하는 현상이 나타나기 때문이다. 이에 각각의 경우(case)에 대해 유량의 균등 분배 정도를 조찰하 기 위함이다.

\subsection{2. 분리막 저항체의 저항계수 결정}

실제 연구대상인 저압 막 모듈의 운전에서는 유입(inflow) 과 유출(outflow) 간의 막 간 차압이 약 $0.6 \mathrm{bar}$ 정도 소요된 다. 이에 본 연구에서는 유입속도 $(U)$ 와 압력 $(p)$ 의 함수로 표 현되는 저항 계수 $\left(C_{\mathrm{R} 1}, C_{\mathrm{R} 2}\right)$ 를 방정식 (1)을 이용하여 적정 값을 구하여 이를 입력변수로 사용하였다. ${ }^{18)}$

$-\frac{d p}{d x}=C_{R 1} U+C_{R 2} U^{2}$

여기서, $p$ 는 압력, $x$ 는 거리, $U$ 는 유동장 내 유속, $C_{\mathrm{R} 1}$ 은 'Linear resistance coefficients'를 마지막으로 $C_{\mathrm{R} 2}$ 는 'Quadric resistance coefficients'를 나타낸다.

상기 관계식을 이용하여 내부 porous 영역의 저항계수 값을 조정하여 유입과 유출구 간에 약 $0.6 \mathrm{bar}$ (정확하게 $0.64804 \mathrm{bar}$ )가 나타나는 저항계수를 'trial and error' 방법 으로 구하였는데 저항 계수는 $1.00 \mathrm{e}+6 \mathrm{~kg} / \mathrm{m}^{4}$ 의 값을 도출 하였다.

\subsection{3. 공간 격자계}

Fig. 8은 본 연구 CFD 모사에 사용된 공간 격자계분포를 나타내고 있다. 격자 형태는 tetra를 사용하였으며, 벽면 근 처에서는 보다 정확한 해상과 수치해석의 정확도를 위하여 상대적으로 조밀한 격자인 prism을 사용하였다. Case 1 단일 격벽을 적용한 경우에는 $1,780,000$ 개의 노드(node) $(7,560,000$

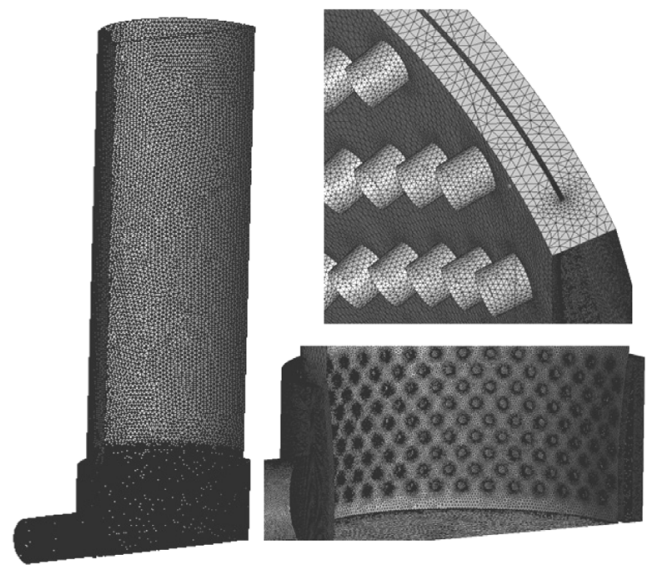

Fig. 8 Meshing works for CFD simulation (case 2 4). elements)로 구성하였으며, case 2, 3, 4 이중 격벽의 경우에 는 $2,350,000$ 개의 노드 $(8,700,000$ elements $)$ 로 구성하였다.

\subsection{4. 지배 방정식}

본 연구에서 $\mathrm{CFD}$ 모사를 위한 지배방정식은 다음 연속, 운동량, 및 에너지 방정식이며, 식 (2) (4)와 같이 나타낸다.

$\frac{\partial \rho}{\partial t}+\frac{\partial}{\partial x_{j}}\left(\rho u_{j}\right)=0$

$\frac{\partial}{\partial t}\left(\rho u_{j}\right)+\frac{\partial}{\partial x_{j}}\left(\rho u_{j} \rho u_{i}\right)=-\frac{\partial P}{\partial x_{j}}+\frac{\partial \tau_{i j}}{\partial x_{j}}+S_{u}$

$\frac{\partial}{\partial t}(\rho H-P)+\frac{\partial}{\partial x_{j}}\left(\rho U_{j} H\right)=\frac{\partial}{\partial x_{j}}\left(k \frac{\partial T}{\partial x_{j}}\right)-\frac{\partial}{\partial x_{j}}\left(u_{j} \tau_{i j}\right)+S_{T}$

여기서, $\rho=$ 밀도, $u_{i}=$ 속도, $P=$ 압력, $\mu=$ 점성계수, $H=$ 전엔 탈피, $h=$ 정적엔탈피, $T=$ 온도, $\tau_{i j}=$ 응력텐서를 나타낸다.

\subsection{5. 난류 모델링}

본 해석에서의 난류 모델링은 $k-\varepsilon$ 난류모델을 사용하였 으며, 난류 모델은 평균성분과 변동성분을 도입하여 수정 된 수송 방정식(transport equation)의 해를 구하기 위한 수 단이다. 전엔탈피( $H$; total enthalpy)는 평균운동에너지(mean kinetic energy)와 난류운동에너지(turbulent kinetic energy) 를 포함한다. 여기서 난류운동에너지는 식 (5)와 같이 정의 된다.

$k=\frac{1}{2} \overline{u^{2}}$

$k$ 는 난류 운동 에너지이며, 속도 변동의 분산으로 정의되고, 차원은 (L2T-2) 즉, $\mathrm{m}^{2} / \mathrm{s}^{2}$ 이다. $\varepsilon$ 은 난류 소산율(turbulence eddy dissipation)이고 단위시간당 $k$ 의 차원을 갖는다. 즉, (L2T-3), $\mathrm{m}^{2} / \mathrm{s}^{3}$ 이다. $k-\varepsilon$ 모델은 기본 방정식에 2 개의 변수 가 추가된다. $k-\varepsilon$ 모델은 난류 점성을 난류 운동에너지와 소산율을 이용하여 다음과 같이 가정한다.

$\mu_{t}=C_{\mu} \rho \frac{k^{2}}{\varepsilon}$

여기서 $\mu_{t}$ 는 난류 점성이며, $C_{\mu}$ 는 상수이다.

\section{3. 입자영상유속 측정 및 분석 방법}

\subsection{1. 실험 장치 구성}

본 연구에서는 $\mathrm{CFD}$ 모사 결과를 검증하기 위해서 입자영 상유속계(particle image velocimetry, PIV)를 이용하여 유입 부 상단의 유속을 실측하였다. 입자영상유속계는 광학 영 


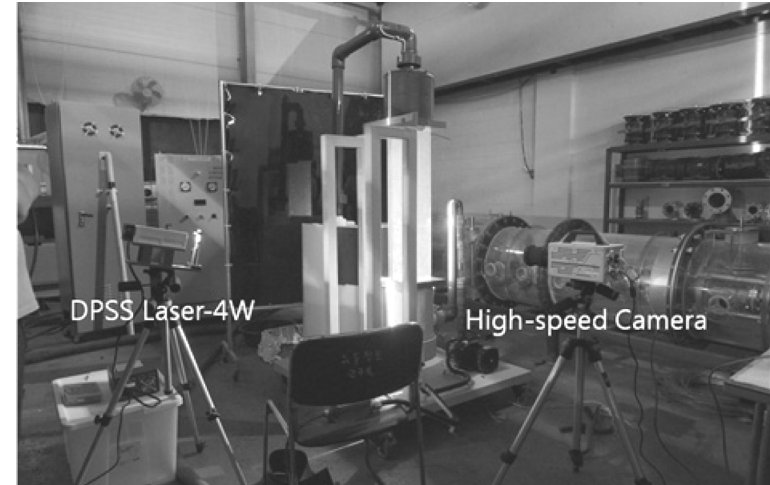

Fig. 9. High speed camera and DPSS (Diode-pumped solid-state) Laser for PIV.

상기술을 이용하여 유동장내의 여러 지점의 속도를 동시 다 발적으로 측정할 수 있는 시스템이다. Fig. 9에서 나타냈듯 이, 실린더 type의 석영렌즈를 이용하여 가시영역대의 레이 저 광선을 확장하여 레이저 영역대(sheet)를 만들고, 이를 대상 영역에 투사시켜 2차원의 유동장을 만들어 낸다. 본 연구에서 사용된 레이저는 DPSS (Diode-pumped Solid-state) 4 watt 용량을 사용하였다. 이 유동장에 추적이 가능한 고 형물인 추적 입자를 충분히 주입하게 되는데 추적 입자는 대상 영역의 유체 흐름을 따라 충분히 작고, 부력의 영향을 받지 않아야 하므로 본 실험에서는 PVC (Poly-vinyl chlorine) 을 사용하였다. 사용한 본 추적 입자의 밀도는 $1.05 \mathrm{~g} / \mathrm{mL}$ 로 써 물과 비슷하여 물의 거동에 따라 움직임이 반영되었다. 본 실험에서 사용한 고속카메라는 최대 초당 7,500 프레임 (frame)을 기록할 수 있고 부분 해상도(segment frame)는 256× 256 Pixels 정도이다.

Fig. 10(a)는 입자영상유속 측정을 위한 가압식 막 모듈 실
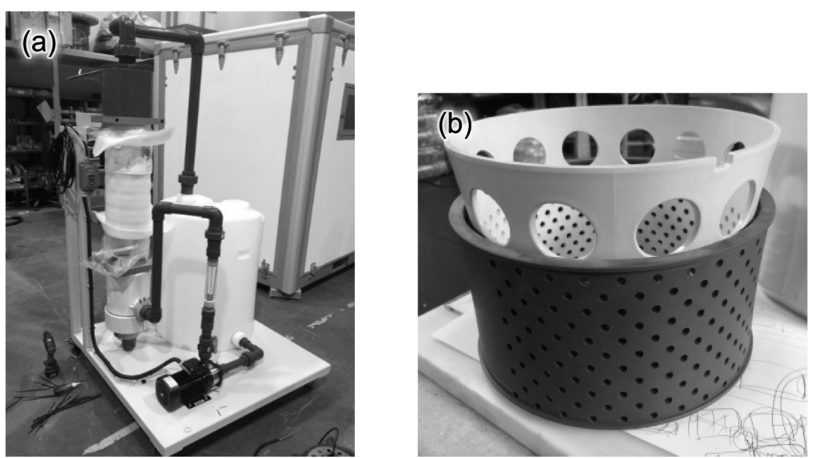

Fig. 10. Membrane module and double baffle inlet structure for PIV measurement.

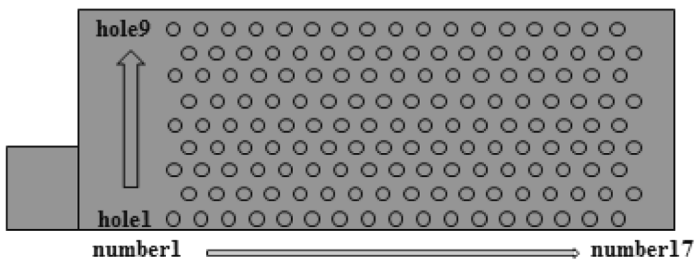

Fig. 12. Hole numbering for comparison.
험장치이다. 지속적인 유동장을 생성하기 위한 펌프, 저장 탱 크 그리고 순환구조의 배관으로 구성되어 있다. Fig. 10(b) 는 $\mathrm{CFD}$ 모사 대상 중 case 3 (각도 $0^{\circ}$ )을 검증하기 위한 이 중격벽 구조를 제작한 것이다. 흰색 부분과 어두운 색 부분 이 각각 이중 격벽 역할을 하게하며 각 격벽의 유공 중심을 일치시켜 실험하였다.

\subsection{2. 후처리 작업}

PIV 후처리 작업에서는 고속카메라를 이용한 동일 입자 축적을 통하여 얻어진 데이터로부터 필요한 정보를 추출하 기 위한 재처리를 한다. 후처리 작업에서는 이상치(outlier) 를 판별하여 제거하는 에러(error) 제거, 격자점 재배치, 픽 셀 단위의 속도벡터를 실단위 $(\mathrm{m} / \mathrm{sec})$ 로 바꾸는 단위환산 등 이 포함되어 있다. ${ }^{19)}$ 다음 Fig. 11은 PIV 실험에서 설정한 계측 단면(a)과 계측한 원시 단면을 나타내었다. PIV 후처 리 및 데이터의 가공을 통하여 속도벡터, 운동에너지 및 난 류 에너지 등의 정량적인 값을 구할 수 있다.

\section{4. 연구 결과 및 토의}

\subsection{CFD 결과}

Fig. 12는 네 가지 case의 CFD 모사 결과를 정량적으로 분 석하기 위해 각각의 유공에 number를 부여한 개념도이다. 유입구를 중심으로 대칭적(symmetry)인 형상이므로 하단 입구측을 'hole 1', 상단 입구측을 'hole 9', 하단 입구측을 'number 1', 그리고 입구측에서 멀어질수록 'number 17'을 임의로 부여하였다. 그리고 본 해석의 입구 조건인 질량 유 량(mass flow)은 $0.8330833 \mathrm{~kg} / \mathrm{s}$ 이며, 유량 균등을 위한 이 상적인 한 개의 유공 유량을 유공의 총 개수(306개)로 나눈 $0.002715 \mathrm{~kg} / \mathrm{s}$ 가 된다.
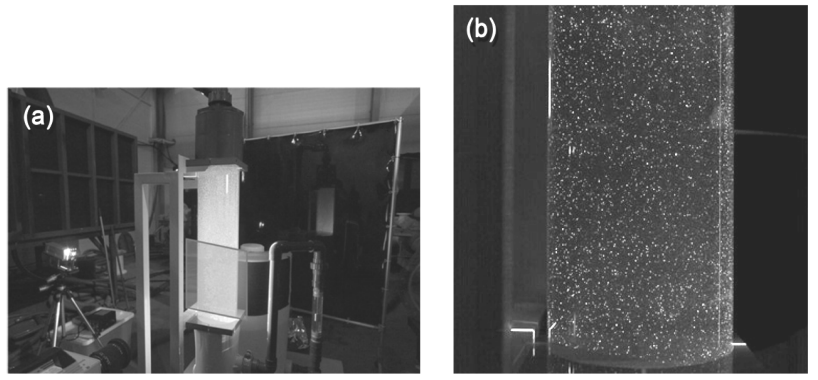

Fig. 11. Measurement section and raw data (video file) for PIV.

\section{E ideal one hole mass flow \\ $=0.002715 \mathrm{~kg} / \mathrm{s}$ \\ - hole mass flow ratio \\ =local hole mass flow / ideal one hole mass flow}


다음 Fig. 13 21은 가장 하단부에 위치한 유공 hole 1 열 이 위치한 평면부터 유공 hole 9(최상단부)에서의 유속 분포 와 스트림라인(streamline) 그리고 속도벡터를 나타낸 결과 이다. Fig. 21은 격벽 유공의 최상단의 평면으로 속도 0.0
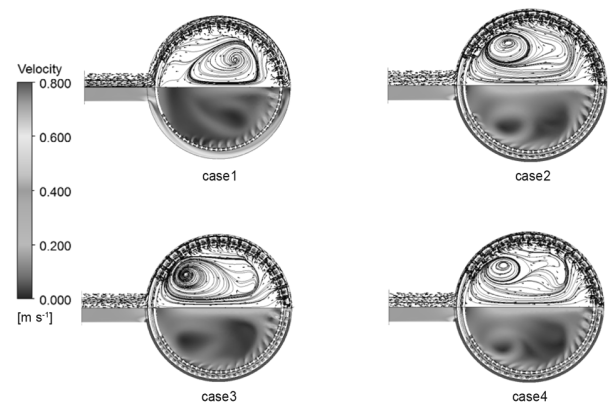

Fig. 13. Velocity contour and streamline on hole 1 plan.
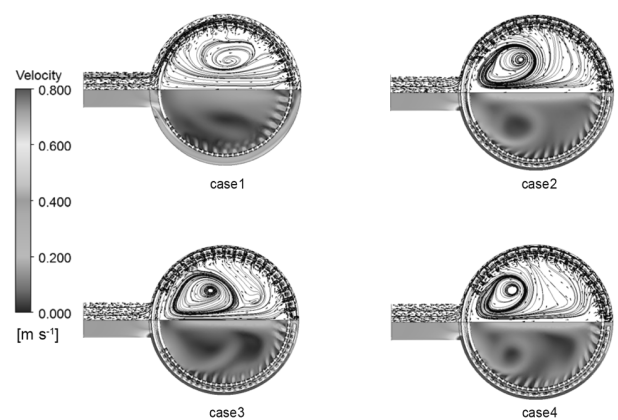

Fig. 15. Velocity contour and streamline on hole 3 plan.
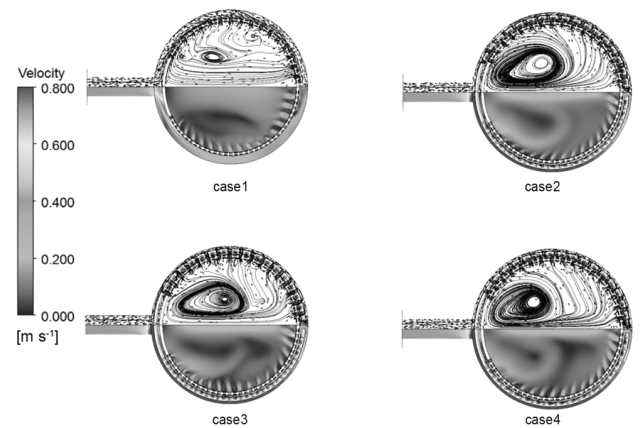

Fig. 17. Velocity contour and streamline on hole 5 plan
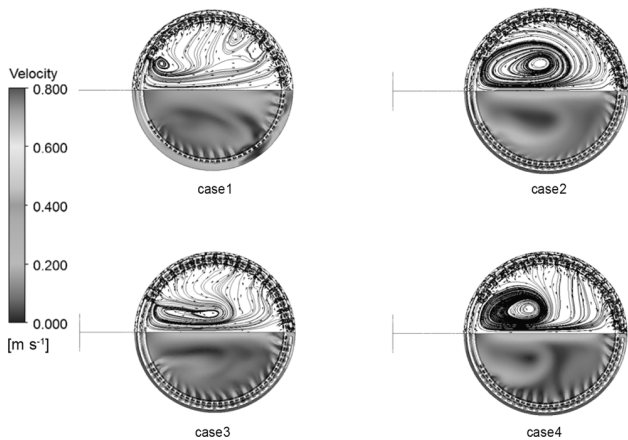

Fig. 19. Velocity contour and streamline on hole 7 plan. $\mathrm{m} / \mathrm{sec} 0.8 \mathrm{~m} / \mathrm{sec}$ 의 범위를 나타낸 것으로써 case 1(단일 격 벽)부터 case 2 4(이중 격벽) 모두 와류가 발생하였다. 특 히 case 2와 case 4에서 상대적으로 큰 와류가 발생하는 것 으로 나타났으며, 이러한 현상은 이중 격벽의 유공의 위치가
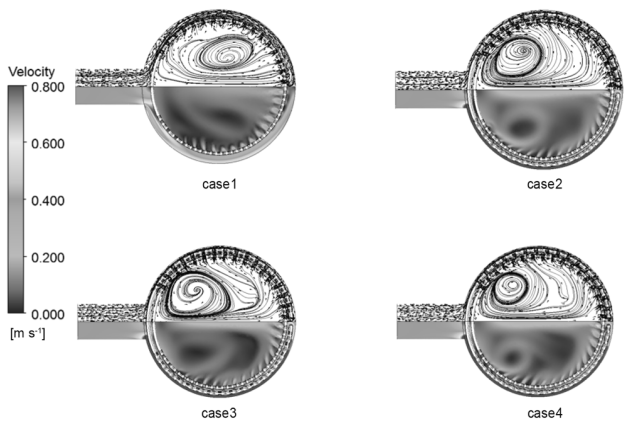

Fig. 14. Velocity contour and streamline on hole 2 plan.
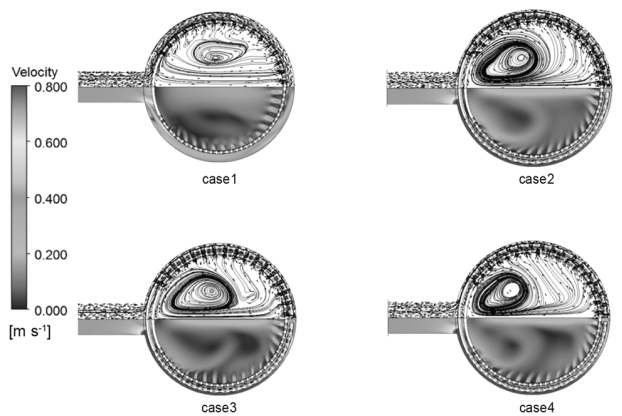

Fig. 16. Velocity contour and streamline on hole 4 plan.

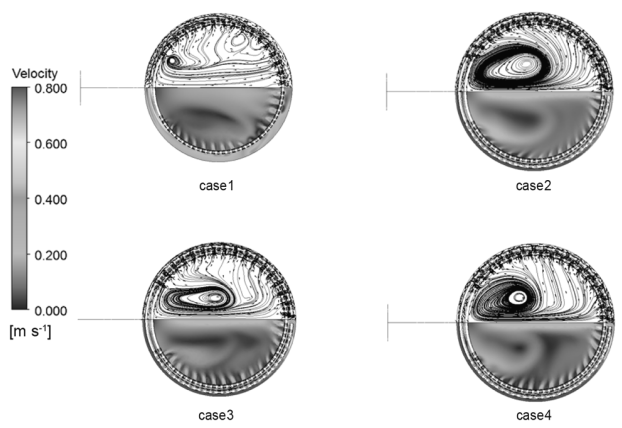

Fig. 18. Velocity contour and streamline on hole 6 plan.

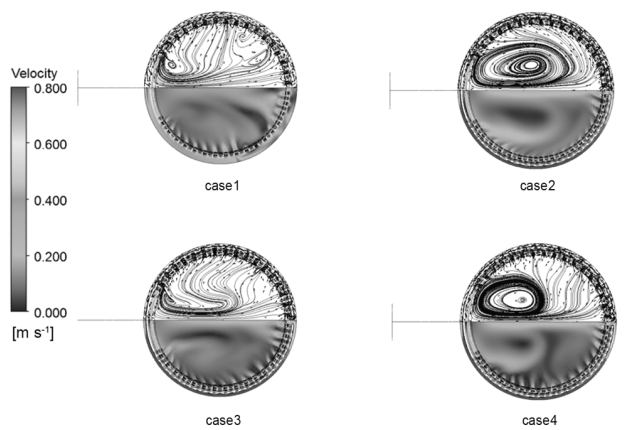

Fig. 20. Velocity contour and streamline on hole 8 plan. 


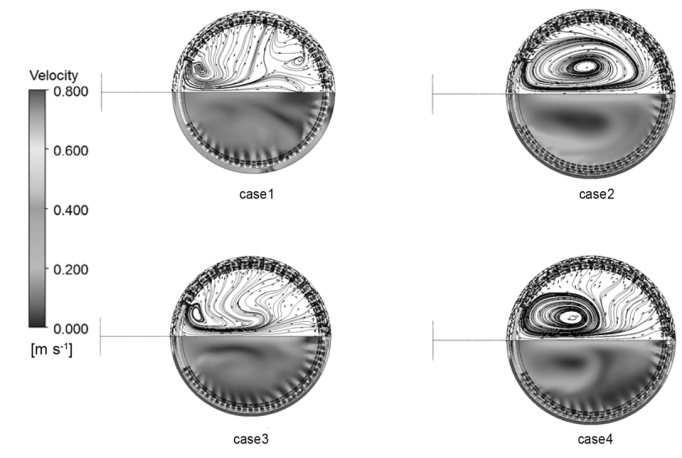

Fig. 21. Velocity contour and streamline on hole 9 plan.

각각 $-3^{\circ}$ 와 $3^{\circ}$ 로 어긋남으로써 발생하는 유동 특성이다. 또 한 이러한 와류의 발달은 유공에서 유출되는 유동의 발달 을 더욱 촉진하는 역할을 한다. Case 1의 유공에서 일부 저 속의 영역이 발생하는 것을 관찰할 수 있다. 그리고 case 1 과 case 2의 유속과 스트림라인의 양상은 유사하게 발생하나 case 3 에서는 상대적으로 낮은 유속대가 발생하지 않는다.

Fig. 20은 hole 8 중심 단면의 결과를 나타낸 것이며, Fig. 21 의 hole 9 단면과 비슷한 결과를 나타내고 있다. Fig. 19는 hole 7 중심 단면에서의 결과를 나타낸 것으로써 case 3 에 서 hole 8 및 9에서 나타난 와류가 크게 나타났으며, case별 로 저속 영역이 나타나지 않았다. 또한 Fig. 17 및 18은 hole 6과 7의 중심 단면에서의 결과로써 상기의 결과와 유사하다.
Fig. 16은 hole 4 단면에서의 결과이며 case 1에서도 case 2 4 에서 발생한 와류가 형성되나, 입구부에서 저속의 영역이 발생하고 유입구의 반대 부분이 격벽 유로 내에서 저속의 영역이 발생하고 있다. 또한 유입구에서 멀어질수록 유속 이 증가함에 따라 유입 유량이 증가한다.

Fig. 13 16은 hole 1에서 4의 중심 단면의 결과이다. Case 1 과 case 2 4의 와류 발생 위치가 상이하게 나타나고 있으 나, case 2 4는 유사한 위치에서 발생하고 있다. 유입구 부 근의 흐름으로 인하여 단면이 급격이 축소되는 격벽 유로 부근에서 빠른 유속이 발생하여 유공을 통하여 막 모듈 내 부로 유입된다.

유공 격벽을 통한 유량 분배는 case 1 의 경우 입구부에서 저속영역이 나타나며, 입구부에서 멀어질수록 빠른 속도 영 역이 발생하였다. 또한 case 2 4의 경우 이중 격벽의 유로 구조로 인하여 격벽 내에서는 빠른 유속이 발생하였다. 이 에 격벽 내의 유속은 입구영역에 가까울수록 빠른 유속이 발 생하였으며, 멀수록 느린 유속이 발생하였다.

다음 Table 2 5는 각 case 별 유공을 통과하는 유량비(mass flow ratio)를 정리한 것이다. 유량비는 국부적인 hole의 유 량에 대하여 이상적인 한 개의 hole의 유량 값을 나눈 것이 다. 그러므로 1 의 값은 가장 이상적인 유량 값이며, 1 보다 작은 값은 이상적인 유량보다 적게 유출되는 것이고, 1 보 다 큰 값은 이상적인 유량보다 크게 유출되는 값이다. 그리

Table 2. Mass flow ratio from each hole in the case 1

\begin{tabular}{|c|c|c|c|c|c|c|c|c|c|c|c|c|c|c|c|c|c|c|}
\hline $\begin{array}{c}\text { Hole } \\
\text { no. }\end{array}$ & 1 & 2 & 3 & 4 & 5 & 6 & 7 & 8 & 9 & 10 & 11 & 12 & 13 & 14 & 15 & 16 & 17 & stvd \\
\hline 9 & 0.971 & 0.820 & & & & & & & & & & & & & & & & \\
\hline 8 & 0.505 & 0.483 & 0.443 & 0.452 & 0 & 722 & 996 & 1.370 & 1.898 & 1.014 & 0.529 & 0.025 & 0.442 & 1.535 & 2.192 & 2.860 & 2.990 & \\
\hline 7 & 0.132 & 0.242 & 0.266 & 0.328 & 0.468 & 617 & 0.880 & 1.267 & 1.654 & 1.943 & 0.807 & 0.161 & 0.090 & 0.987 & 1.777 & 2.459 & 2.791 & 042 \\
\hline 6 & 0.087 & 0.185 & 0.302 & 0.426 & 0.556 & 0.759 & 1.108 & 1.493 & 1.811 & 1.386 & 0.475 & 0.188 & 0.565 & 1.335 & 1.964 & 2.556 & 2.882 & 1.428853 \\
\hline 5 & -0.092 & 0.175 & 0.278 & 0.421 & 0.547 & 0.768 & & & 1.582 & 1.648 & 1.080 & 0.569 & 0.475 & 0.801 & 1.538 & 2.408 & 2.619 & \\
\hline 4 & -0.102 & -0.052 & 0.204 & 0.309 & 0.406 & 0.565 & 0.819 & 1.002 & 1.149 & 1.127 & 0.9 & 0.765 & 0.862 & 1.280 & 2.097 & 2.465 & 2.895 & 1.077429 \\
\hline 3 & -0.450 & -0.340 & -0.104 & 0.066 & 0.203 & 0.322 & 0.540 & 0.775 & 0.951 & 0.951 & 0.847 & 0.802 & 0.899 & 1.222 & 1.840 & 2.330 & 2.583 & 0.979735 \\
\hline 2 & -0.476 & -0.270 & -0.050 & 0.130 & 0.284 & 0.413 & 0.588 & 0.754 & 0.916 & 0.958 & 0.910 & 1.012 & 1.384 & 1.843 & 2.049 & 2.387 & 2.939 & 0.951609 \\
\hline 1 & -0.382 & -0.324 & -0.114 & 0.108 & 0.225 & 0.313 & 0.424 & 0.567 & 0.715 & 0.807 & 0.920 & 1.095 & 1.432 & 2.051 & 1.812 & 2.075 & 2.534 & 0.856359 \\
\hline
\end{tabular}

${ }^{*}$ stvd $=$ standard deviation

Table 3. Mass flow ratio from each hole in the case 2

\begin{tabular}{|c|c|c|c|c|c|c|c|c|c|c|c|c|c|c|c|c|c|c|}
\hline $\begin{array}{c}\text { Hole } \\
\text { no. }\end{array}$ & 1 & 2 & 3 & 4 & 5 & 6 & 7 & 8 & 9 & 10 & 11 & 12 & 13 & 14 & 15 & 16 & 17 & stvd \\
\hline 9 & 2.229 & 2.097 & 1.968 & 1.910 & 2.005 & 2.448 & 2.161 & 0.959 & 1.799 & 2.275 & 2.208 & 2.142 & 2.165 & 2.212 & 2.339 & 2.487 & 2.611 & 1.659967 \\
\hline 8 & 1.833 & 1.842 & 1.870 & 1.896 & 2.027 & 2.510 & 1.478 & 0.839 & 1.779 & 1.902 & 2.071 & 2.024 & 1.997 & 1.994 & 2.070 & 2.172 & 2.209 & 1.47474 \\
\hline 7 & 1.443 & 1.484 & 1.620 & 1.661 & 1.629 & 1.727 & 1.934 & 0.736 & 1.268 & 1.511 & 1.580 & 1.637 & 1.633 & 1.602 & 1.602 & 1.696 & 1.779 & 1.305875 \\
\hline 6 & 1.185 & 1.309 & 1.404 & 1.427 & 1.394 & 1.441 & 1.356 & 0.989 & 1.082 & 1.060 & 1.134 & 1.201 & 1.215 & 1.218 & 1.271 & 1.376 & 1.488 & 1.124602 \\
\hline 5 & 0.767 & 0.813 & 0.817 & 0.846 & 0.855 & 0.868 & 0.726 & 0.555 & 0.571 & 0.575 & 0.621 & 0.701 & 0.799 & 0.882 & 0.972 & 1.084 & 1.193 & 1.003876 \\
\hline 4 & 0.352 & -0.444 & 0.490 & 0.474 & 0.438 & 0.404 & 0.256 & 0.172 & 0.284 & 0.327 & 0.379 & 0.484 & 0.600 & 0.724 & 0.887 & 1.035 & 1.259 & 0.906401 \\
\hline 3 & -0.339 & -0.234 & 0.040 & 0.161 & 0.220 & 0.218 & 0.220 & 0.127 & 0.137 & 0.167 & 0.192 & 0.282 & 0.412 & 0.554 & 0.703 & 0.880 & 1.049 & 0.727441 \\
\hline 2 & -0.436 & -0.249 & -0.021 & 0.151 & 0.230 & 0.255 & 0.209 & 0.122 & 0.077 & 0.088 & 0.159 & 0.291 & 0.474 & 0.604 & 0.736 & 0.922 & 1.303 & 0.573843 \\
\hline 1 & -0.305 & -0.249 & -0.079 & 0.117 & 0.206 & 0.191 & 0.141 & 0.086 & 0.053 & 0.044 & 0.093 & 0.231 & 0.454 & 0.666 & 0.563 & 0.762 & 1.049 & 0.390618 \\
\hline
\end{tabular}


Table 4. Mass flow ratio from each hole in the case 3

\begin{tabular}{|c|c|c|c|c|c|c|c|c|c|c|c|c|c|c|c|c|c|c|}
\hline $\begin{array}{c}\text { Hole } \\
\text { no. }\end{array}$ & 1 & 2 & 3 & 4 & 5 & 6 & 7 & 8 & 9 & 10 & 11 & 12 & 13 & 14 & 15 & 16 & 17 & stvd \\
\hline 9 & 2.388 & 2.202 & 2.056 & 1.986 & 2.098 & 2.560 & 2.232 & 1.502 & 2.068 & 2.214 & 2.182 & 2.172 & 2.199 & 2.228 & 2.358 & 2.493 & 2.606 & 1.632731 \\
\hline 8 & 1.937 & 1.930 & 1.939 & 1.935 & 2.091 & 2.360 & 1.022 & 1.457 & 1.792 & 1.938 & 2.011 & 2.009 & 1.994 & 1.987 & 2.071 & 2.166 & 2.204 & 1.461501 \\
\hline 7 & 1.602 & 1.614 & 1.729 & 1.715 & 1.643 & 1.743 & 1.691 & 1.310 & 1.482 & 1.525 & 1.567 & 1.617 & 1.611 & 1.567 & 1.575 & 1.669 & 1.753 & 1.285696 \\
\hline 6 & 1.321 & 1.413 & 1.467 & 1.436 & 1.342 & 1.349 & 1.279 & 1.103 & 1.029 & 1.044 & 1.110 & 1.160 & 1.158 & 1.156 & 1.207 & 1.299 & 1.422 & 1.136169 \\
\hline 5 & 0.892 & 0.881 & 0.853 & 0.853 & 0.833 & 0.807 & 0.607 & 0.495 & 0.513 & 0.538 & 0.574 & 0.647 & 0.727 & 0.790 & 0.870 & 0.972 & 1.073 & 1.022055 \\
\hline 4 & 0.425 & -0.486 & 0.506 & 0.460 & 0.390 & 0.330 & 0.204 & 0.207 & 0.266 & 0.273 & 0.328 & 0.418 & 0.512 & 0.619 & 0.770 & 0.911 & 1.123 & 0.911486 \\
\hline 3 & -0.296 & -0.182 & 0.097 & 0.177 & 0.199 & 0.168 & 0.173 & 0.138 & 0.159 & 0.138 & 0.156 & 0.239 & 0.347 & 0.469 & 0.604 & 0.772 & 0.927 & 0.691686 \\
\hline 2 & -0.404 & -0.211 & 0.038 & 0.188 & 0.232 & 0.246 & 0.208 & 0.147 & 0.091 & 0.074 & 0.132 & 0.238 & 0.394 & 0.527 & 0.648 & 0.818 & 1.186 & 0.508241 \\
\hline 1 & -0.266 & -0.195 & -0.005 & 0.202 & 0.255 & 0.220 & 0.168 & 0.123 & 0.092 & 0.056 & 0.073 & 0.170 & 0.349 & 0.577 & 0.495 & 0.666 & 0.930 & 0.28374 \\
\hline
\end{tabular}

Table 5. Mass flow ratio from each hole in the case 4

\begin{tabular}{|c|c|c|c|c|c|c|c|c|c|c|c|c|c|c|c|c|c|c|}
\hline $\begin{array}{c}\text { Hole } \\
\text { no. }\end{array}$ & 1 & 2 & 3 & 4 & 5 & 6 & 7 & 8 & 9 & 10 & 11 & 12 & 13 & 14 & 15 & 16 & 17 & stvd \\
\hline 9 & 2.617 & 2.381 & 2.202 & 2.135 & 2.366 & 2.980 & 1.216 & 1.611 & 2.221 & 2.258 & 2.212 & 2.229 & 2.229 & 2.260 & 2.377 & 2.496 & 2.601 & 1.619485 \\
\hline 8 & 2.106 & 2.072 & 2.056 & 2.048 & 2.385 & 2.259 & 0.680 & 1.702 & 1.979 & 2.011 & 2.011 & 2.019 & 1.989 & 1.998 & 2.068 & 2.152 & 2.193 & 1.459749 \\
\hline 7 & 1.851 & 1.810 & 1.875 & 1.787 & 1.685 & 1.956 & 1.206 & 1.055 & 1.583 & 1.569 & 1.594 & 1.616 & 1.590 & 1.542 & 1.554 & 1.633 & 1.719 & 1.274302 \\
\hline 6 & 1.537 & 1.563 & 1.548 & 1.448 & 1.300 & 1.365 & 1.143 & 1.080 & 1.024 & 1.048 & 1.093 & 1.119 & 1.098 & 1.091 & 1.128 & 1.203 & 1.338 & 1.127446 \\
\hline 5 & 1.115 & 0.998 & 0.921 & 0.890 & 0.845 & 0.789 & 0.541 & 0.485 & 0.504 & 0.505 & 0.532 & 0.592 & 0.646 & 0.689 & 0.754 & 0.835 & 0.919 & 1.012907 \\
\hline 4 & 0.567 & -0.571 & 0.547 & 0.459 & 0.353 & 0.251 & 0.129 & 0.205 & 0.226 & 0.227 & 0.277 & 0.339 & 0.401 & 0.480 & 0.603 & 0.730 & 0.930 & 0.905799 \\
\hline 3 & -0.210 & -0.027 & 0.229 & 0.221 & 0.180 & 0.106 & 0.099 & 0.117 & 0.138 & 0.109 & 0.136 & 0.198 & 0.275 & 0.365 & 0.473 & 0.621 & 0.756 & 0.711922 \\
\hline 2 & -0.346 & -0.106 & 0.177 & 0.239 & 0.232 & 0.232 & 0.197 & 0.144 & 0.086 & 0.078 & 0.119 & 0.191 & 0.306 & 0.430 & 0.540 & 0.684 & 1.030 & 0.545313 \\
\hline 1 & -0.184 & -0.067 & 0.264 & 0.361 & 0.342 & 0.284 & 0.232 & 0.194 & 0.137 & 0.068 & 0.069 & 0.125 & 0.240 & 0.441 & 0.417 & 0.545 & 0.776 & 0.344801 \\
\hline
\end{tabular}

고 음의 값은 역유동이 발생하는 것이다. 즉 baffle이 hole 을 통하여 유출되는 것이 아니고 유입되는 것을 의미한다. hole을 통하여 유출되는 유량은 baffle의 입구부에서 멀어 질수록 이상적인 유량 대비 약 2 배 이상으로 유출되고 있 는 것을 알 수 있다.
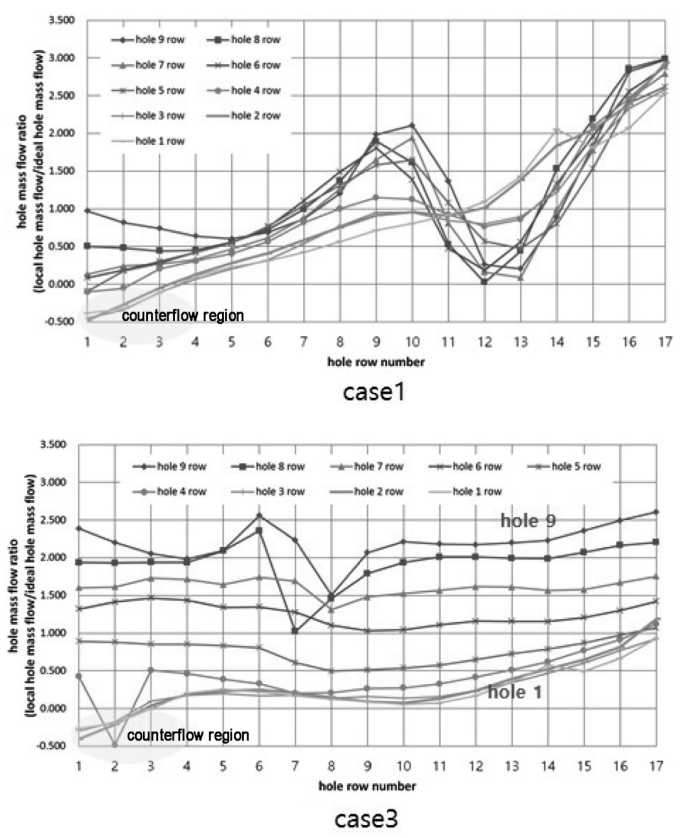

Fig. 22. Inlet flow distribution in 4 cases.
자세한 case 간의 비교를 위해 유공별로 유출되는 유량을 표준 편차로 비교한 결과 case 1 은 1.33 , case 2 는 1.02 , case 3 은 0.98 마지막으로 case 4는 1.00 으로 계산되어졌다. 이로 case 1 과 case 3 을 비교한 결과 약 $40 \%$ 이상의 유량 균등 정 도의 제고가 나타났다. 각 유공별 모듈내로 유입되는 유량
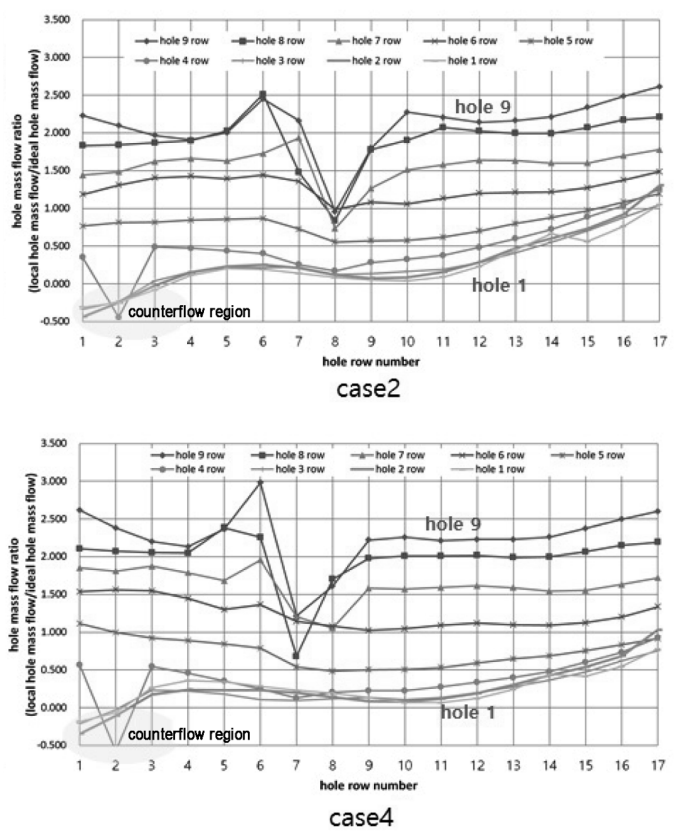
을 상대적으로 비교하기 위하여 꺽은 선 그래프를 이용하 여 각 case의 상대적 유입 유량을 다음 Fig. 22와 같이 도시 하였다. X축은 유공(hole)의 number를 나타내는 것이며, 이 는 “1”이 유입구에서 가장 가까운 유공을 뜻하며, ‘ 17 '은 가 로방향으로 유입구의 반대편 유입구에서 가장 먼 유공을 나 타낸다. Y축은 Table 2 5에서 정리한 유량비(mass flow ratio) 를 무차원 수로 표현하였다. 각 case에서 유입구와 가까운 1 번과 2 번 유공에서는 물이 역류되는 음(-)의 영역대의 역 류영역이 발생하는데, 특히 이중 격벽이 설치된 case 2 4에 서는 4 번 유공 중심단면에서는 유독 2 번 유공에서 역류가 발생하는 것으로 나타났다(Fig. 22. 역류 영역 참조). 이는 모듈내 유입구의 높이가 4번 유공 중심단면과 일치함에 따 라 이 높이에서 높은 에너지 소산이 발생함에 따라 와류가 형성되기 때문임을 알 수 있다. 또한 네 가지 case 모두 유 입구의 반대편인 유공 17 로 갈수록 모듈 내 유입 유량이 증가하는 것으로 나타나는 데 그 정도가 단일 격벽인 경우 가 가장 높게 나타나고, 이중 유공 격벽을 설치한 case 2 4 의 경우 증가 정도가 상대적으로 낮은 것으로 관측되었다. 이와 같은 결과는 앞서 언급한 표준 편차의 절대값으로 잘 설명된 바이다. 단일 유공 격벽(case 1)의 경우 유공 12 번에 서 유입유량이 한번 극소를 나타남에 반해 이중 유공 격벽
을 설치한 경우(case 2 4)에는 유공 7번 또는 8 번에서 극소 값을 나타내고 있다.

\section{2. 입자영상유속(PIV)측정 결과}

상기에서 언급한 바와 같이 $\mathrm{CFD}$ 모사 결과를 검증하기 위해 대상 중 case 3 (유공 홀의 편차 각도 $0^{\circ}$ )를 대상으로 막 모듈 내부에 이중격벽 구조를 제작하고 2차원 유속을 실측하였다. Fig. 23은 오른 쪽에 유입구를 두고 입자영상 유속계를 측정한 결과를 평균 속도분포 벡터로 나타낸 것 이다. (a)는 단일 유공 격벽이 설치된 경우이며 CFD 모사 에 있어서 case 1을 의미하며, (b)는 이중 유공 격벽을 설치 한 경우인데 유공 편차 각도가 $0^{\circ}$ 인 case 3 을 대상으로 실 험한 것이다. PIV 실험을 수행하는 동안 관측할 수 있었던 것은 두 가지 경우 모두 유입구의 반대편 유공에서 많은 유 량이 유입되는 것이 관측되었다. PIV실험에 있어서는 내부 할로우 파이버가 없는 상태에서 유속을 측정하였기 때문에 반대편 유공에서 유입된 유속 모멘텀이 유입구측 측벽을 타 고 상부로 올라가는 주된 흐름을 발생시키는 것으로 관측 되었다. 이러한 위치별 유공을 통한 유입 유량의 편차는 (a) 의 단일 격벽보다 (b)의 이중 격벽에서 그 현상이 현저히 감 소하는 것으로 나타남을 알 수 있었다.

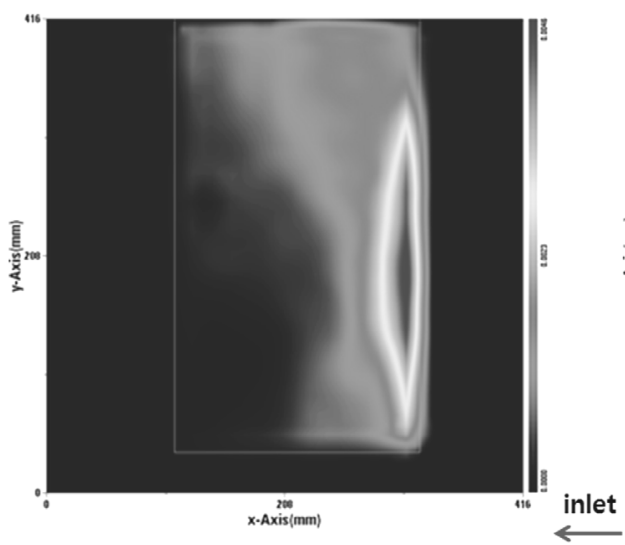

(a) case 1

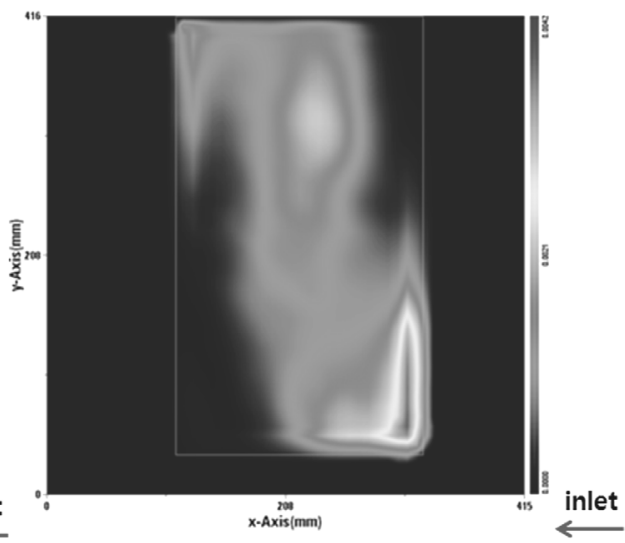

(b) case 3

Fig. 23. The results of PIV measurement (Average velocity distribution).

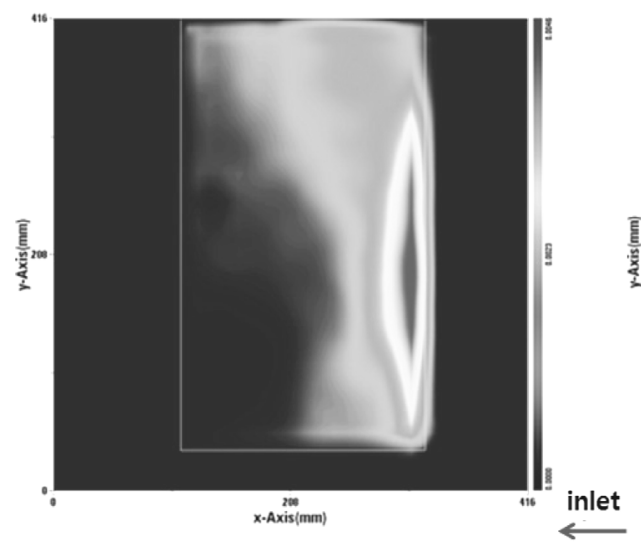

(a) case 1

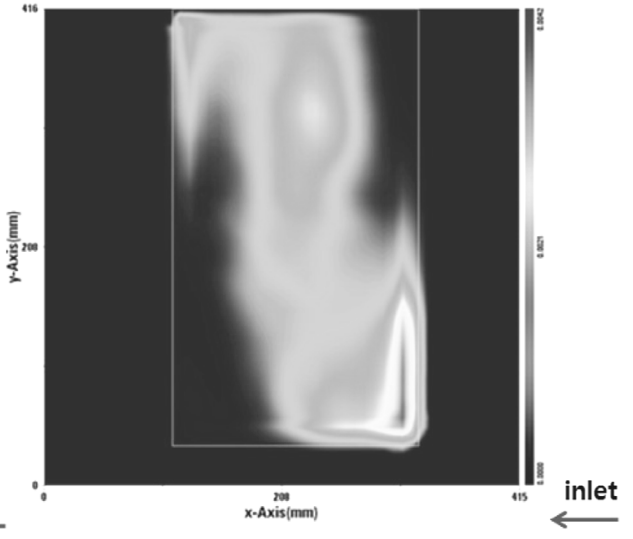

(b) case 3

Fig. 24. The results of PIV measurement (Average kinetic energy distribution). 
다음 Fig. 24는 PIV 측정 결과를 평균 운동에너지 분포로 도시한 것이다. 마찬가지로 (a)는 단일 유공 격벽이 설치된 경우이며 (b)는 이중 유공 격벽을 설치한 경우이다. Fig. 1 의 일정 기간을 사용한 막 모듈의 절단면에서 유입구 반대 편에 오염이 집중된 현상과 $\mathrm{CFD}$ 의 모사 결과 유입구 반대 편 유공에서 막 모듈 내부로 들어오는 수체의 유속이 상대 적으로 커 이 수체의 모멘텀이 유입구 측벽에 강한 전단력 을 발생하지만 유입구 반대 측벽에서는 사류가 형성됨을 확 인하였다. 막 표면에 강한 전단력이 발생하는 경우 표면이 상대적으로 깨끗하게 유지될 수 있지만 전단력이 약하면 입 자의 물질 전달이 감소하여 표면이 오염될 우려가 커지는 것을 예측할 수 있다. 이에 Fig. 24 실측한 운동에너지의 분 포는 사용한 막 모듈의 오염 현상과 선행된 CFD 모사 결과 를 검증할 수 있는 좋은 증명 자료가 된다.

\section{5. 결 론}

본 연구에서는 실규모의 사이드 스트림 방식의 막 모듈을 대상으로 하단에 위치한 유입부의 수리구조를 개선하여 모 듈로 유입되는 유입 유량을 수직으로 균등하게 분포시킬 수 있는 방안을 제시하고 이를 실험적으로 검증하고자 하였 다. 이에 다음과 같은 결론을 도출하였다.

1) 실규모 사이드 스트림 방식의 막 모듈을 대상으로 유입 유량을 수직으로 균등하게 분포시킬 수 있는 방안을 $\mathrm{CFD}$ 로 설계한 결과, 내부 유입 수리구조에 유공 격벽을 설치함 으로써 모듈내로의 유입유량은 표준편차 기준으로 약 $40 \%$ 정도 감소됨을 확인하였으며 균등하게 분배하기 위한 내부 유공 격벽 설치가 효과가 있음을 결론지을 수 있다.

2) 선행된 $\mathrm{CFD}$ 결과를 검증하고 사이드 스트림 막 모듈 의 편중된 오염의 원인을 조사하기 위해 수행된 입자영상유 속 측정 결과로부터 유입구 반대편 유공에서 막 모듈 내부 로 들어오는 수체의 유속이 상대적으로 커 이 수체의 모멘 텀이 유입구 측벽에 강한 전단력을 발생하지만 유입구 반대 측벽에서는 사류가 형성됨을 확인하였다.

3) 본 연구는 아직까지 이중 유공 격벽의 설치로 인한 에 너지 손실-현재 $\mathrm{CFD}$ 모사 결과로는 $0.05 \mathrm{bar}$ 가 더 소요됨의 검증, 유입구 수리구조를 변경하고 난 후의 장기간 실험 을 통한 오염 발생 양상 조사, 막 모듈 내로의 유입 유량의 균등화를 더욱 더 제고시킬 수 있는 방안 제시 등 지속적 인 연구의 진행이 필요하다.

\section{Acknowledgement}

본 연구는 2014년도 산업통상자원부의 재원으로 한국산 업기술진흥원(KIAT)의 지원을 받아 수행한 연구과제(N0001232)입니다.

\section{References}

1. Li, Y. L. and Tung, K. L., "CFD simulation of fluid flow through spacer-filled membrane module: selecting suitable cell types for periodic boundary conditions," Desalination, 233, 351 358(2008).

2. Owen, G., Bandi, M., Howell, J. A. and Churchouse, S. J., "Economic assessment of membrane process for water and waste water treatment," J. Membr. Sci., 102, 77 91(1995).

3. Guo, H., Wyart, Y., Perot, J., Nauleau, F. and Moulin, P., "Low-pressure membrane integrity tests for drinking water treatment: A review," Water Res., 44, 41 57(2010).

4. David, H., Furukawa, P. E. and Ch, E., "NWRI Final Project Report: a Global Perspective of Low Pressure Membrane," USA, California(2008).

5. Brehant, A., Glucina, K., Lemoigne, I. and Laine, J. M., Risk Mangement Approach for Monitoring UF Membrane Integrity and Experimental Validation using MS2-phages. IWA World Water Congress, Austria Vienna(2008).

6. Huang, H., Schwab, K. and Jacangelo, J. G., "Pretreatment for Low Pressure Membrane in Water Treatment: A Review," Environm. Sci. Technol., 43(9), 3011 3019(2009).

7. Zhu, B. T., Clifford, D. A. and Chellam, S., "Virus removal by iron coagulation-microfiltration." Water Res., 39(20), 5153 5161(2005).

8. Yan, M., Wang, D., Ni, J., Qu, J., Chow, C. W. K. and Liu, $\mathrm{H}$., "Mechanism of natural organic matter removal by polyaluminum chloride: Effect of coagulant particle size and hydrolysis kinetics," Water Res., 42(3), 3361 3370(2008).

9. Kim, J., Cai, Z. and Benjamin, M. M., "Effects of adsorbents on membrane fouling by natural organic matter," J. Membr. Sci., 310(1-2), 356 364(2008).

10. Clark, M. M., Ahn, W. Y., Li, X., Sternisha, N. and Riley, R. L., "Formation of polysulfone colloids for adsorption of natural organic foulants," Langmuir, 21(16), 7207 7213 (2005).

11. Plummer, J. D. and Edzwald, J. K., "Effects of chlorine and ozone on algal cell properties and removal of algae by coagulation," J. Water Supply Res. Technol.-AQUA-, 51(6), 307 318(2002).

12. Wang, X., Wang, L., Liu, Y. and Duan, W., "Ozonation pretreatment for ultrafiltration of the secondary effluent," $J$. Membr. Sci., 287(2), 187 191(2007).

13. Koh, M., Clark, M. A. and Howe, K. J., "Filtration of lake natural organic matter: Adsorption capacity of a polypropylene microfilter," J. Membr. Sci., 256(1-2), 169 175 (2005).

14. Sakol, D. and Konieczny, K., "Application of coagulation and conventional filtration in raw water pretreatment before microfiltration membranes," Desalination, 162(1-3), 61 73 (2004).

15. Park, N. S., Kim, S., Lee, Y. and Wang C., "Effects of 
Longitudinal Baffles on Particles settling in a Sedimentation Basin," Water Sci. Technol., 69(6), 1212 1218(2014).

16. Kim, S., Park, N. S., Jeong, W. and Wang, C., "Process control systems of granular media filter considering daily flow-rate fluctuation," Desalination and Water Treat., 51(3739), 6978 6984(2013).

17. Lee, A., Park, N. S., Kim, S. and Kim, N., "Physical modification to improve a channel's flow distribution," Korean J. Chem. Eng., 29(2), 201 208(2012).

18. ANSYS, ANSYS CFX Tutorials, ANSYS, Inc., Southpointe U.S.A(2009).

19. Rajendran, V. P. and Patel, V. C., "Measurement of Vortices in Model Pump Intake Bay by PIV," J. Hydraulic Eng., ASCE, 126(5), 322 334(2000). 